\begin{tabular}{|c|c|c|c|}
\hline $\begin{array}{l}\text { Cose Reports in } \\
\text { inc.anty }\end{array}$ & $\begin{array}{l}\text { Case Rep Oncol 2010;3:182-188 } \\
\text { D0I: 10.1159/000315366 }\end{array}$ & Published online: June 8, 2010 & $\begin{array}{l}\text { ( ) } 2010 \text { S. Karger AG, Basel } \\
\text { ISSN } 1662-6575 \\
\text { www.karger.com/cro }\end{array}$ \\
\hline
\end{tabular}

\title{
Acute Fatal Liver Toxicity under Erlotinib
}

\author{
Sabina Schacher-Kaufmann Miklos Pless \\ Division of Medical Oncology, Department of Internal Medicine, Winterthur, \\ Switzerland
}

\section{Key Words}

Erlotinib · Non-small cell lung cancer $\cdot$ NSCLC $\cdot$ Liver toxicity $\cdot$ Hepatopathy

\begin{abstract}
We describe the case of a never-smoker who received second-line erlotinib as a treatment for his non-small cell lung cancer. Within one month, acute hepatic failure developed as well as a thrombotic-thrombocytopenic microangiopathy, with fatal outcome. In patients with non-small cell lung cancer, hepatic toxicity of erlotinib is a rare but severe complication; so far three fatal cases have been reported. Patients' liver function should be assessed before starting erlotinib and special care is recommended if pretreatment bilirubin is elevated.
\end{abstract}

Erlotinib (Tarceva ${ }^{\circledR}$ ) is an oral, reversible epidermal growth factor receptor (EGFR) tyrosine-kinase inhibitor. The drug was approved by the FDA in 2004 for treatment of patients with locally advanced or metastasized non-small cell lung cancer (NSCLC) and in 2005 , in combination with gemcitabine, for treatment of patients with pancreatic cancer, both on the basis of randomized phase III studies $[1,2]$. In a clinical phase I study, a daily dose of $150 \mathrm{mg}$ proved to be the maximum tolerated dose, the dose-limiting toxicities being diarrhea, skin reactions und fatigue [3]. Serious liver dysfunction was rarely found in phase III studies $[1,2,4]$. However, in the last two years there have been a number of case reports on acute, severe liver toxicity with erlotinib $[5,6]$, a few with a fatal outcome $[7,8]$. We are describing the case of a patient with metastasized NSCLC, who developed acute liver failure with a fatal coagulation complication under erlotinib treatment.

\section{Case Report}

A 53-year-old never-smoker was diagnosed with a deep leg vein thrombosis and one month later with an adenocarcinoma of the lung (negative for EGFR mutation and EML4-ALK translocation), stage IVB with a malignant pleural effusion. A nonproductive cough had been the only symptom. Anticoagulation with low molecular weight heparin (LMWH) was started, overlapping with phenprocoumon. A palliative chemotherapy with 4 cycles of cisplatin/vinorelbine was given, which 
resulted in a partial remission. Ten weeks later, the patient complained of a deterioration of his performance status, and pulmonary and pleural tumor progression as well as the suspicion of a new liver metastasis were diagnosed (fig. 1a). Laboratory results showed an anemia of $115 \mathrm{~g} / 1$, otherwise normal hematology; ASAT/ALAT, alkaline phosphatase and creatinine were within the normal range, bilirubin $19 \mu \mathrm{mol} / \mathrm{l}(<17)$, LDH $587 \mathrm{U} / \mathrm{l}(<450)$. A second-line therapy with a daily dose of $150 \mathrm{mg}$ erlotinib was started.

On the ninth day of therapy, the patient was bedridden, complained of lack of appetite and reported being unable to walk. Clinically, he was in a bad general condition with a performance status 3 . A discrete folliculitis of the thoracic aperture and a relapse of the leg vein thrombosis were found, but there was no evidence of neurological pathologies. Phenprocoumon was stopped and LMWH was resumed in a therapeutic dose. The laboratory results showed constant anemia, discrete signs of cholestasis, further elevated lactate dehydrogenase (LDH) and minor renal insufficiency. The transaminases were not measured. We interpreted the general condition to be a consequence of the tumor and the recurring deep vein thrombosis. Erlotinib was continued.

On the 17th day of therapy, the patient was hospitalized due to further deterioration of his general condition, with a fever of $39.6^{\circ} \mathrm{C}$, vomiting and upper abdominal pain. A slight anemia of $110 \mathrm{~g} / \mathrm{l}$ was found, Lc were $11.7 \times 10^{9} / \mathrm{l}$, Tc $291 \times 10^{9} / \mathrm{l}$, INR 4.55 , bilirubin $20 \mu \mathrm{mol} / \mathrm{l}$, alkaline phosphatase $475 \mathrm{U} / \mathrm{l}$, LDH 1,856 U/l, ASAT 1,011 U/l, ALAT 2,050 U/l, creatinine $120 \mu \mathrm{mol} / \mathrm{l}$, CRP $132 \mathrm{mg} / \mathrm{l}$ (fig. 2). Blood cultures and serologies for hepatitis $\mathrm{A}, \mathrm{B}$ and $\mathrm{C}$ were negative.

The abdominal ultrasound showed a severely inhomogeneous liver, as well as progression of the liver metastasis in segment II and thickening of the gall bladder. The differential diagnosis at this point was acute hepatitis or cholangitis and an antibiotic therapy with ciprofloxacin und metronidazole was initiated. Erlotinib was stopped since drug-induced hepatitis could not be excluded.

On day 24 after starting erlotinib, the patient complained of excruciating pain in his right upper abdomen. Another rise in temperature was documented. The lab results showed an anemia of $\mathrm{Hb} 118$ $\mathrm{g} / \mathrm{l}$, Lc $21.9 \times 10^{9} / \mathrm{l}$, Tc $134 \times 10^{9} / \mathrm{l}$, some fragmentocytes, INR 1.68 , fibrinogen $1.7 \mathrm{~g} / \mathrm{l}(2-4)$, factor II $49 \%$ (70-120), factor V 64\% (70-140), bilirubin $80 \mu \mathrm{mol} / \mathrm{l}$, alkaline phosphatase $814 \mathrm{U} / \mathrm{l}$, LDH 5,841 U/l, ASAT 3,511 U/l, ALAT $884 \mathrm{U} / \mathrm{l}$, creatinine $100 \mu \mathrm{mol} / \mathrm{l}$, CRP 149mg/l (fig. 2). A CT scan revealed a pulmonary and pleural tumor progression, edema of the gallbladder and also fresh hypodense areas in the liver and hypodensities of the kidney and the upper pole of the spleen, which were interpreted as necrosis (fig. 1b). Sonographically, the portal vein was dilated. The patient was put on hydration, and allopurinol and vitamin K were given; LMWH was continued.

On day 30, acral necrosis of the toes was found. All peripheral pulses were palpable. The lab results showed constant anemia with elevated reticuloytes $276 \times 10^{9} / 1(35-105)$, a further drop in factor $\mathrm{V}$, antithrombin III 23\% (75-120), haptoglobin $0.2 \mathrm{~g} / \mathrm{l}$ (0.6-3.6), a negative result in the PF4 antibody and the direct Coombs test, an increase in bilirubin with unchanged alkaline phosphatase and declining transaminases (fig. 2). The diagnosis of thrombotic microangiopathy with compensated hemolysis was made and an antithrombin III substitution with fresh frozen plasma was started.

A heparin-induced thrombocytopenia was ruled out because of the lack of PF4 antibodies. After unstoppable deterioration of his general condition, the patient died three days later.

\section{Consent}

The patient has unfortunately passed away and could not give his informed consent. There is no immediate family to be contacted. All patient data are completely anonymized.

\section{Discussion}

This unfortunate patient died of acute liver failure, most likely due to erlotinib. First, there was a rapidly progressive hepatopathy, which led to hospitalization 17 days after initiating erlotinib. The patient presented a clinical picture of acute hepatitis. A second row of events began on the seventh day of hospitalization with massive liver necrosis and signs of a blood coagulation disorder. 
We attribute the acute hepatitis to the medication with erlotinib. The drug is metabolized hepatically through the enzymes CYP3A4 und CYP1A2 of cytochrome P450. Drug interaction can therefore affect the metabolism of erlotinib and possibly increase the toxicity. During the first week of therapy, the only other comedication the patient took was phenprocoumon. Phenprocoumon is partially inactivated by CYP3A4. When giving erlotinib and coumarines simultaneously, an increase in INR but not in erlotinib clearance has been described [12]. Consequently, we do not think that the combination was the cause of the described toxicity.

The time course of the liver toxicity correlates with other documented case reports (table 1). Presently it is unclear why exclusively cases with lung cancer took a fatal course. Perhaps this is merely a quantitative problem; erlotinib is used in many more patients with NSCLC than in patients with other cancers. Alternatively, the dose of erlotinib might be relevant. In patients with pancreatic cancer, erlotinib was dosed mostly at $100 \mathrm{mg} /$ day in combination with gemcitabine [2]. In this study, the grade 3/4 liver toxicities were comparable between gemcitabine alone and the combination of erlotinib and gemcitabine (grade 3 elevation of ASAT/ALAT 18 vs. 23\%, of bilirubin 10\% in both groups), and were likely to be tumor-related. In phase III studies in NSCLC patients, no [4] or just moderate liver enzyme increases ( $4 \%$ grade 2 vs. $0 \%$ [1]) were found. However, only patients without [1], or with liver enzyme increase grade $\leq 1$ [4] were included in these trials. This is also the case for the phase I study [3], in which a therapy-associated bilirubinemia grade 1 is described in 8/40 patients, but transaminases did not increase. More recent pharmacokinetic data of patients with preexisting liver function problems are not conclusive $[9,10]$. The most significant factor to impair drug clearance seems to be increased bilirubin [9]. Miller et al. [10] come to the conclusion that patients with pretherapeutic liver dysfunction should be started on a reduced dose of erlotinib of 75 $\mathrm{mg} /$ day.

It is not known why a few patients react to erlotinib with such massive toxicity. Pharmacogenomical studies have shown polymorphisms on the CYP3A4- as well as on the CYP3A5-gene and have investigated their effect on the pharmacokinetics of erlotinib [11]. No clear correlation was found, not even on commonly observed toxicities such as exanthema or diarrhea. Further pharmacogenetic research is warranted.

Recently published cases of acute liver toxicity under erlotinib have caused OSI Pharmaceuticals and Genentech to inform the physicians of this data in a 'Dear Doctor' letter in September 2008 and to amend the drug information accordingly. References to 'hepatotoxicity' and 'patients with hepatic impairment' now appear in the chapter 'warnings' [12]. Special caution is indicated in patients with pretreatment elevations of bilirubin, but no dose reduction of erlotinib is suggested.

This patient's course was complicated by a blood coagulation disorder. On the seventh day in the hospital, at the time of the massive liver necrosis, first symptoms of a microangiopathic and disseminated coagulopathy occurred: fragmentocytes, thrombocytopenia, diminished fibrogen as well as factor V. It can be assumed that the cause of the coagulation disorder was multifactorial, the extensive liver cell necrosis being an important contributing factor. Considering the patient's history with a deep vein thrombosis as the first symptom of his malignancy, there was probably a tumorassociated coagulopathy involved as well, which is a common paraneoplastic symptom, frequently seen in adenocarcinomas of the lung $[13,14]$. A direct link between erlotinib monotherapy and coagulopathy seems less likely; there are no reports in the literature to support such a hypothesis. Two cases of patients with pancreatic cancer and treatment with erlotinib and gemcitabine who developed microangiopathic hemolytic anemia with 
thrombocytopenia have been described; this complication was, however, most likely caused by gemcitabine [15]. Thus, we believe that the coagulopathy was not a direct consequence of erlotinib but rather an indirect effect of erlotinib-induced acute hepatitis.

We are describing the third case of a fatal liver toxicity in a patient with adenocarcinoma of the lung under treatment with erlotinib. It is estimated that each year more than 100 '000 patients receive erlotinib. Therefore, fortunately, this seems to be a very rare complication [16]. However, because of its severity, we think it is important that prescribing physicians know about this potential danger. We suggest monitoring liver function tests after initiating erlotinib, and stopping treatment if there is a suspicion of drug-induced hepatitis. Patients with preexisting elevations of bilirubin should be monitored with special care and in these patients reducing the dose of erlotinib could be considered $[9,10]$.

Table 1. Summary of published cases of erlotinib-induced acute liver toxicity

\begin{tabular}{|c|c|c|c|c|c|c|c|}
\hline & Diagnosis & $\begin{array}{l}\text { Age/ } \\
\text { sex }\end{array}$ & $\begin{array}{l}\text { Dose of } \\
\text { erlotinib } \\
\text { mg }\end{array}$ & $\begin{array}{l}\text { Concomitant } \\
\text { drug }\end{array}$ & $\begin{array}{l}\text { Known liver } \\
\text { function } \\
\text { abnormality }\end{array}$ & $\begin{array}{l}\text { Time to first } \\
\text { elevation } \\
\text { LFT }\end{array}$ & $\begin{aligned} & \text { Outcome } \text { Time to } \\
& \text { recover } \\
& \text { LFT }\end{aligned}$ \\
\hline $\begin{array}{l}\text { Liu et al., } 2007 \\
{[7]}\end{array}$ & lung cancer & $67 / F$ & $\begin{array}{l}150 \\
100 \text { by } \\
\text { reinduction }\end{array}$ & none & none & $\begin{array}{l}\text { day } 14 \\
\text { day } 10 \text { after } \\
\text { reinduction }\end{array}$ & fatal \\
\hline $\begin{array}{l}\text { Ramanarayanan } \\
\text { and Scarpace, } \\
2007 \text { [5] }\end{array}$ & $\begin{array}{l}\text { pancreatic } \\
\text { cancer }\end{array}$ & $70 / \mathrm{M}$ & 100 & gemcitabine & none & day 14 & recovered 6 weeks \\
\hline Saif, 2008 [6] & $\begin{array}{l}\text { pancreatic } \\
\text { cancer }\end{array}$ & $52 / \mathrm{M}$ & 100 & gemcitabine & none & week 7 & recovered 8 weeks \\
\hline $\begin{array}{l}\text { Pellegrinotti et al., } \\
2009 \text { [8] }\end{array}$ & lung cancer & $77 / \mathrm{M}$ & 100 & $\begin{array}{l}\text { oral antidiabetic } \\
\text { omeprazole } \\
\text { prednisone } \\
\text { furosemide }\end{array}$ & none & day 12 & fatal \\
\hline Present case & lung cancer & $53 / \mathrm{M}$ & 150 & $\begin{array}{l}\text { phenpro- } \\
\text { coumon }\end{array}$ & $\begin{array}{l}\text { liver } \\
\text { metastasis }\end{array}$ & day 10 & fatal \\
\hline
\end{tabular}

LFT $=$ Liver function tests. 


\begin{tabular}{c|l|l|l}
$\begin{array}{c}\text { Case Reports in } \\
\text { Oncolady }\end{array}$ & $\begin{array}{l}\text { Case Rep Oncol 2010;3:182-188 } \\
\text { D0I: 10.1159/000315366 }\end{array}$ & Published online: June 8, 2010 & $\begin{array}{l}\text { O 2010 S. Karger AG, Basel } \\
\text { ISSN 1662-6575 } \\
\text { www.karger.com/cro }\end{array}$ \\
\hline
\end{tabular}

Fig. 1. a 4 days before the initiation of therapy. b 24th day of erlotinib treatment.

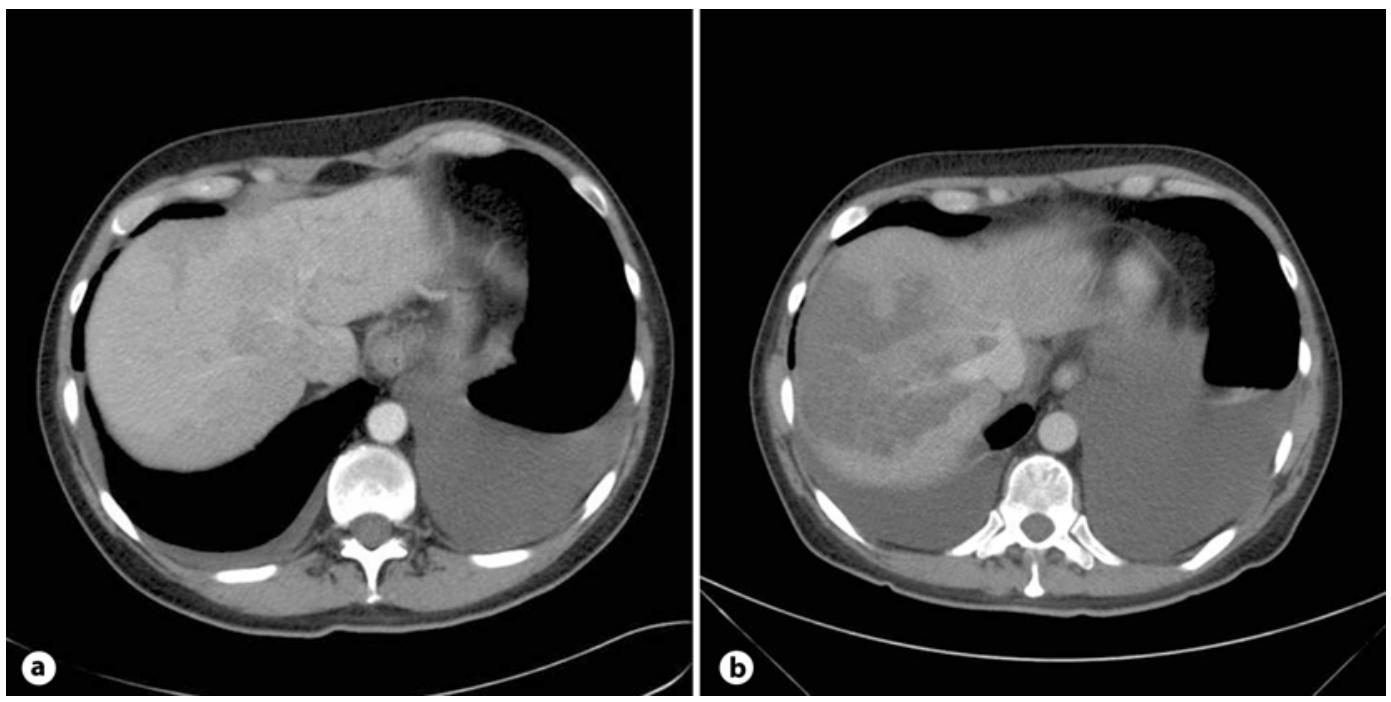


Fig. 2. Evolution of laboratory parameters.

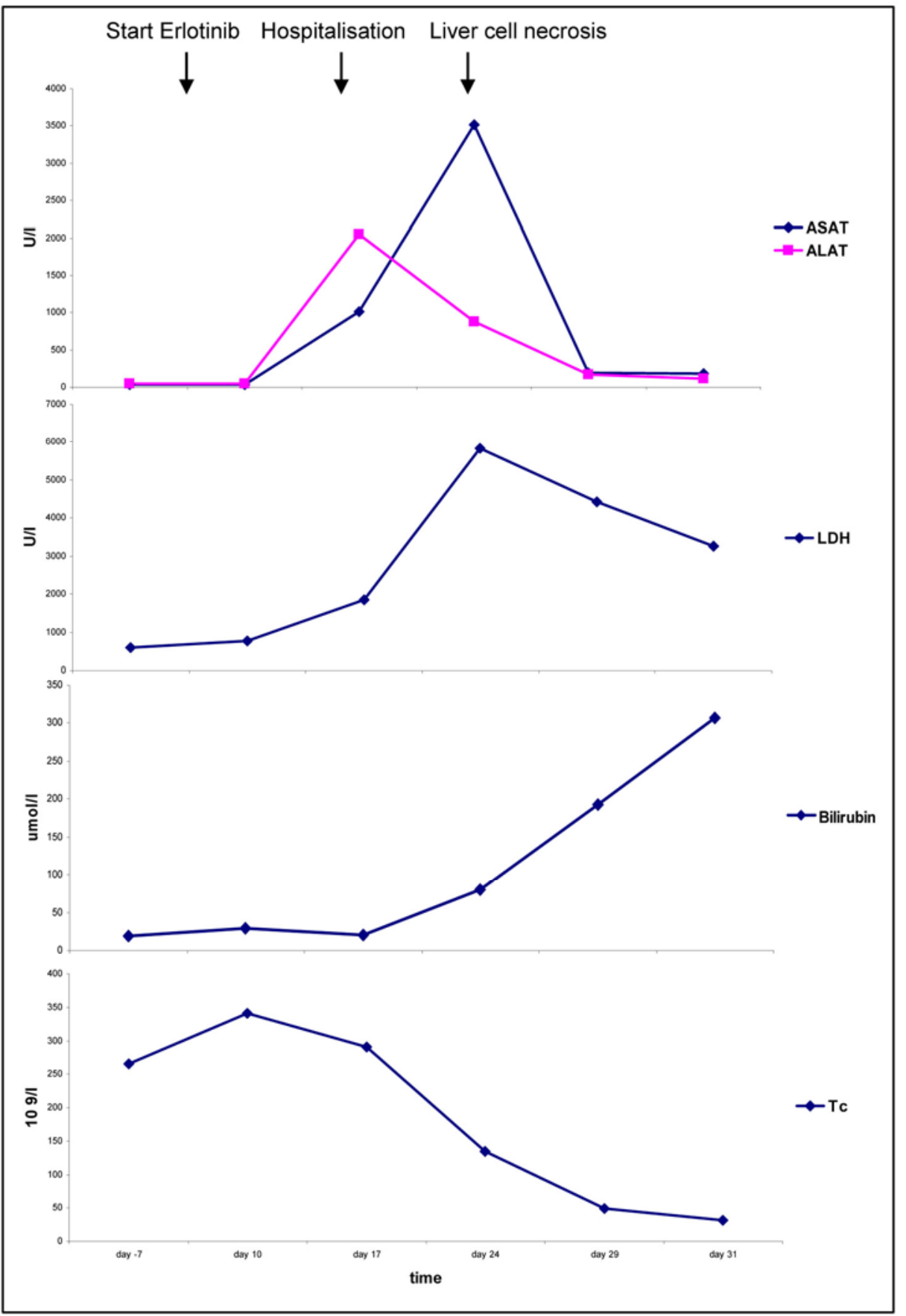




\begin{tabular}{|c|c|c|c|}
\hline $\begin{array}{l}\text { Cose Reports in } \\
\text { Cincialy }\end{array}$ & $\begin{array}{l}\text { Case Rep Oncol 2010;3:182-188 } \\
\text { Dol: 10.1159/000315366 }\end{array}$ & Published online: June 8, 2010 & $\begin{array}{l}\text { (c) } 2010 \text { S. Karger AG, Basel } \\
\text { ISSN } 1662-6575 \\
\text { www.karger.com/cro }\end{array}$ \\
\hline
\end{tabular}

\section{References}

1 Shepherd FA, Rodrigues Pereira J, Ciuleanu T, et al: Erlotinib in previously treated non-small lung cancer. N Engl J Med 2005;353:123-132.

-2 Moore MJ, Goldstein D, Hamm J, et al: Erlotinib plus gemcitabine compared with gemcitabine alone in patients with advanced pancreatic cancer: a phase III trial of the National Cancer Institute of Canada Clinical Trials Group. J Clin Oncol 2007;25:1960-1966.

3 Hidalgo M, Siu LL, Nemunaitis J, Rizzo J, Hammond LA, Takimoto C, et al: Phase I and pharmacologic study of OSI-774, an epidermal growth factor receptor tyrosine kinase inhibitor, in patients with advanced solid malignancies. J Clin Oncol 2001;s19:3267-3279.

-4 Herbst RS, Prager D, Hermann R, Fehrenbacher L, Johnson BE, Sandler A, et al: TRIBUTE: a phase III trial of erlotinib hydrochlorid (OSI-774) combined with carboplatin and paclitaxel chemotherapy in advanced non-small-cell lung cancer. J Clin Oncol 2005;23:5892-5899.

5 Ramanarayanan J, Scarpace SL: Acute drug induced hepatitis due to erlotinib. J Pancreas 2007;8:39-43.

-6 Saif MW: Erlotinib-induced acute hepatitis in a patient with pancreatic cancer. Clin Adv Hematol Oncol 2008;6:191-199.

\ Liu W, Markauer FL, Qamar AA, Jänne PA, Odze RD: Fulminant hepatic failure secondary to erlotinib. Clin Gastroenterol Hepatol 2007;5:917-920s.

-8 Pellegrinotti M, Fimognari FL, Franco A, Repetto L, Pastorelli R: Erlotinibinduced hepatitis complicated by fatal lactic acidosis in an elderly man with lung cancer. Ann Pharmacother 2009;43:542-545.

-9 Lu JF, Eppler SM, Wolf J, Hamilton M, Rakhit A, Bruno R, Lum BL: Clinical pharmacokinetics of erlotinib in patients with solid tumors and exposure-safety relationships in patients with non-small cell lung cancer. Clin Pharmacol Ther 2006;80:136-145.

10 Miller A, Murry D, Owzar K, Hollis D, Lewis L, Kindler H, Marshall J, et al: Phase I and pharmacokinetic study of erlotinib for solid tumors in patients with hepatic or renal dysfunction: CALGB 60101. J Clin Oncol 2007;25:3055-3060.

11 Rudin Ch, Liu W, Desai A, Karrison T, Jiang X, et al: Pharmacogenomic and pharmacokinetic determinants of erlotinib toxicity. J Clin Oncol 2007;26:11191127.

12 Genentech, Inc (2008) http://www.gene.com/gene/products/information/pdf/tarceva-pr (accessed 1 October 2008).

13 Tagalakis V, Levi D, Agulnik JS, Cohen V, Kasymjanova G, Small D: High risk of deep vein thrombosis in patients with non-small cell lung cancer: a cohort study of 493 patients. J Thorac Oncol 2007;2:729-734.

14 Blom JW, Osanto S, Rosendaal FR: The risk of a venous thrombotic event in lung cancer patients: higher risk for adenocarcinoma than squamous cell carconoma. J Thromb Haemost 2004;2:1760-1765.

15 Izzedine $\mathrm{H}$, Isnard-Bagnis $\mathrm{C}$, Launay-Vacher V, Mercadal L, Tostivint I, et al: Gemcitabine-induced thrombotic microangiopathy: a systemic review. Nephrol Dial transplant 2006;21:3038-3045.

16 Roche Pharmaceuticals, annual report 2008;39. 